\title{
Interference of Meloidogyne javanica in the reproduction of Pratylenchus brachyurus in soybean cultivar BRS/MT pintado
}

\author{
Lais Fernanda Fontana ${ }^{2}$, Claudia Regina Dias Arieira ${ }^{1}$, Vinicius Hicaro Frederico Abe ${ }^{1}$, José Junior Severino ${ }^{1}$, Jailson \\ de Oliveira Arieira ${ }^{1}$, Raimundo Nonato Farias Monteiro ${ }^{2}$.
} \begin{abstract}
Filho", 18610-307, Campus de Botucatu, Botucatu, SP, Brasil.
Autor para correspondência: Lais Fernanda Fontana (laisffontana@hotmail.com).

Data de chegada: 14/03/2017. Aceito para publicação em: 15/09/2017.
\end{abstract}

${ }^{1}$ Universidade Estadual de Maringá, Câmpus Umuarama, 87020-900, Umuarama, PR, Brasil; ${ }^{2}$ Universidade Estadual Paulista "Júlio de Mesquita

\section{ABSTRACT}

Fontana, L.F.; Arieira, c.r.d.; Abe1, V.H.F.; Severino, J.J.; Arieira, J.O.; Monteiro, R.N.F. Interference of Meloidogyne javanica in the reproduction of Pratylenchus brachyurus in soybean cultivar BRS/MT pintado. Summa Phytopathologica, v.44, n.2, p.143-147, 2018.

Root-knot nematodes, Meloidogyne spp., and the root-lesion nematode, Pratylenchus brachyurus, are the most common phytoparasites in soybean crop, which usually occur in association in crop areas. However, few studies were conducted on the interaction between these parasites. Therefore, this study aimed to assess the interference of the increase in $M$. javanica population in the reproduction of $P$. brachyurus, and the effect of mixed populations on soybean (cultivar BRS/MT Pintado) development. The experiment consisted in inoculating a population of 1000 specimens of $P$. brachyurus per plant and changing the inoculum level of M. javanica, using zero, 1000, 2000 and 4000 eggs, in two different periods. After 65 days of inoculation, the increase in the initial population of $M$. javanica reduced by 79 and $73 \%$ the final population of P. brachyurus in the different experiments. However, both species significantly increased their populations. When subjected to the same inoculum level, $M$. javanica was more efficient in reproducing than $P$. brachyurus. The increase in the number of nematodes reduced the vegetative growth of the plant.

Keywords: Glycine max, interactions, root-knot nematodes, root-lesion nematodes, mixed populations

\section{RESUMO}

Fontana, L.F.; Arieira, c.r.d.; Abe1, V.H.F.; Severino, J.J.; Arieira, J.O.; Monteiro, R.N.F. Interferência de Meloidogyne javanica na reprodução de Pratylenchus brachyurus em soja cultivar BRS/MT pintado. Summa Phytopathologica, v.44, n.2, p.143-147, 2018.

Os nematoides das galhas, Meloidogyne spp., e o nematoide das lesões radiculares, Pratylenchus brachyurus, são os fitoparasitas mais comuns na cultura da soja e comumente ocorrem associados nas áreas de cultivo. Porém, poucos são os estudos da interação existente entre eles. Assim, objetivou-se avaliar a interferência do aumento da população de $M$. javanica sobre a reprodução de $P$. brachyurus, e o efeito das populações mistas no desenvolvimento da soja cv. BRS/MT Pintado. O experimento consistiu em inocular uma população de 1000 espécimes de $P$. brachyurus por planta e variar o nível de inóculo de M. javanica, usando zero, 1000, 2000 e 4000 ovos, e foi conduzido em duas épocas distintas. Após 65 dias da inoculação, observou-se que o aumento na população inicial de $M$. javanica reduziu em 79 e $73 \%$ a população final de $P$. brachyurus, nos diferentes experimentos. Porém, ambas as espécies aumentaram significativamente as populações. Quando submetidos ao mesmo nível de inóculo, $M$. javanica foi mais eficiente em reproduzir-se do que P. brachyurus. O aumento no número de nematoides reduziu o desenvolvimento vegetativo da planta.

Palavras-chave: Glycine max, Interações, Nematoides das galhas, Nematoides das lesões radiculares, Populações mistas

Soybean is the most important oilseed crop in the world and has increased in percentage more than the major grain crops, particularly because its market has obtained a solid structure worldwide, the plant has been recognized as an important source of vegetable protein and technology has been generated, allowing the crop expansion to different regions of the world (17).

Although soybean planted areas and productivity have continuously grown, maximum yield potential $(4000 \mathrm{~kg} / \mathrm{ha})$ is hard to obtain in most countries. The main factors that limit the yield, the profitability and the success of soybean production are diseases, including nematodes which cause significant losses to the Brazilian production, varying from slight to complete $(100 \%)(2,11)$.

Species of Meloidogyne, particularly Meloidogyne javanica (Treub) Chitwood and M. incognita (Kofoid and White) Chitwood, represent a serious problem in soybean producing regions (18). Data on specific yield losses caused by these two species are common and vary among the different crop areas or regions (1), reaching up to $40 \%$ in low fertility sandy soils.

Another nematode that has a significant impact on Brazilian soybean production is Pratylenchus brachyurus (Godfrey) Filipjev and Schuurmans Stekhoven. It is an aggressive species that heavily infest soybean producing areas $(5,18)$. Crop losses caused by this nematode are estimated to range from 10 to $30 \%$ of the production potential, especially in areas showing sandy soil and irregular rainfall distribution (5). Nevertheless, declines of up to $50 \%$ in soybean production have already been recorded for commercial crops infested by $P$. brachyurus in the central-west region of Brazil (14), and losses are greater when the infection is associated with other important nematode species (18).

The above-mentioned species commonly occur concomitantly in annual crops, which was already reported in Paraná (25), in cities of 
Minas Gerais and Goiás $(20,24)$ and in the states of Mato Grosso and Mato Grosso do Sul $(2,26)$. Although few studies were conducted on the interaction of these species, Meloidogyne spp. have been reported to show competitive advantage over $P$. brachyurus in soybean $(10,16)$. On the other hand, the intense initial attack by Pratylenchus followed by massive root destruction is believed to represent a serious problem to the growth of Meloidogyne population (23). This variation occurs because competitive advantage is influenced by different factors, including host susceptibility, host cultivars and nematode population $(16,23)$. Thus, the present study aimed to assess the influence of the growing population of $M$. javanica on the reproduction of $P$. brachyurus, as well as the effect on soybean cultivar BRS/MT Pintado.

\section{MATERIAL AND METHODS}

The experiments were conducted in a greenhouse, in the Experimental Farm of "Universidade Estadual de Maringá", Umuarama Regional Campus, Paraná, in completely randomized design, with four treatments and five replicates each, in two different periods: from May to July 2013 (Experiment 1), and from September to November 2013 (Experiment 2).

Soybean seedlings of cultivar BRS/MT Pintado were produced in polystyrene trays and, when the phenological stage V1 was reached, they were transplanted to $2-\mathrm{L}$ plastic pots containing a mixture of soil:sand (2:1) sterilized through a cycle of two hours at $120^{\circ} \mathrm{C}$.

Two days after transplanting, the soybean was inoculated with an initial population of 1000 specimens of $P$. brachyurus per plant and with a variable inoculum level of $M$. javanica, using zero, 1000, 2000 and 4000 eggs per plant. The nematodes were obtained from pure populations of $P$. brachyurus and $M$. javanica multiplied in soybean and tomato plants, respectively, in plastic pots kept in a greenhouse for two months. Nematodes were extracted according to the methodology proposed by Hussey and Barker, adapted by Boneti \& Ferraz (3).

Sixty-five days after inoculation, soybean plants were collected by separating the roots and the shoot. The root systems were washed and placed on absorbent paper to remove excess water; then, they were weighed and the root fresh weight was determined. Subsequently, the nematodes were extracted from the root system according to the cited methodology.

Nematode suspensions were maintained at $27^{\circ} \mathrm{C}$ for five days to

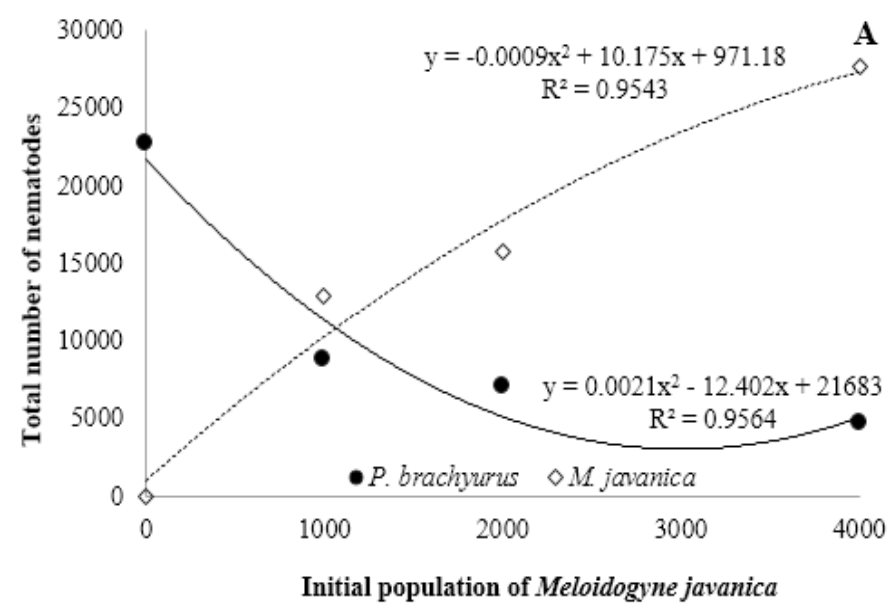

allow the hatching of juveniles. Then, samples were examined under an optical microscope at $100 \mathrm{X}$ magnification, and the total number of specimens of $M$. javanica and P. brachyurus was counted separately. This value was divided by the root weight to obtain the number of nematodes per gram of root (nematode/g root). The shoot was evaluated for the plant height. Measurements were also taken to obtain shoot fresh and dry weight; the latter was determined after drying in an aircirculation oven for 72 hours at $65^{\circ} \mathrm{C}$.

The obtained data were subjected to analysis of variance and means were compared according to regression test at 5\% probability, using SISVAR statistical analysis program (12).

\section{RESULTS AND DISCUSSION}

In both experiments, analysis of variance was significant for nematological and vegetative parameters. In experiment $1, P$. brachyurus population increased by $2166 \%$ when there was no inoculum of M. javanica (Figure 1A). On the other hand, inoculating the maximum population of $M$. javanica (4000 eggs), such an increase declined to $369 \%$. The results obtained in experiment 2 confirmed the increase of $2715 \%$ in $P$. brachyurus when the initial population of $M$. javanica was zero. However, the increase in $M$. javanica population to 4000 eggs led to an increase of $659 \%$ in P. brachyurus population (Figure 1B).

Inoculating both species with the same concentration of nematodes (1000), M. javanica population was greater than P. brachyurus population, showing increases of 1183 and $771 \%$ in experiment 1 , for the respective nematodes (Figure 1A), and 1506 and $1168 \%$ in experiment 2 (Figure 1B).

The results obtained for the parameter number of nematodes/g root were similar to those obtained for the total number of nematodes. In experiment 1 , when the initial population of $M$. javanica was zero, the number of $P$. brachyurus/g root was equivalent to 465.4, but for an initial population of 4000 eggs of $M$. javanica, the number of $P$. brachyurus/g root was 141.6, which is equivalent to a reduction of $69.0 \%$ (Figure 2A). Likewise, in experiment 2, the increase in the initial population of $M$. javanica from zero to 4000 eggs decreased $P$. brachyurus population by $65 \%$ (Figure $2 \mathrm{~B}$ ).

All vegetative parameters reduced following the increase in the initial population of the root-knot nematode. The increase in $M$. javanica

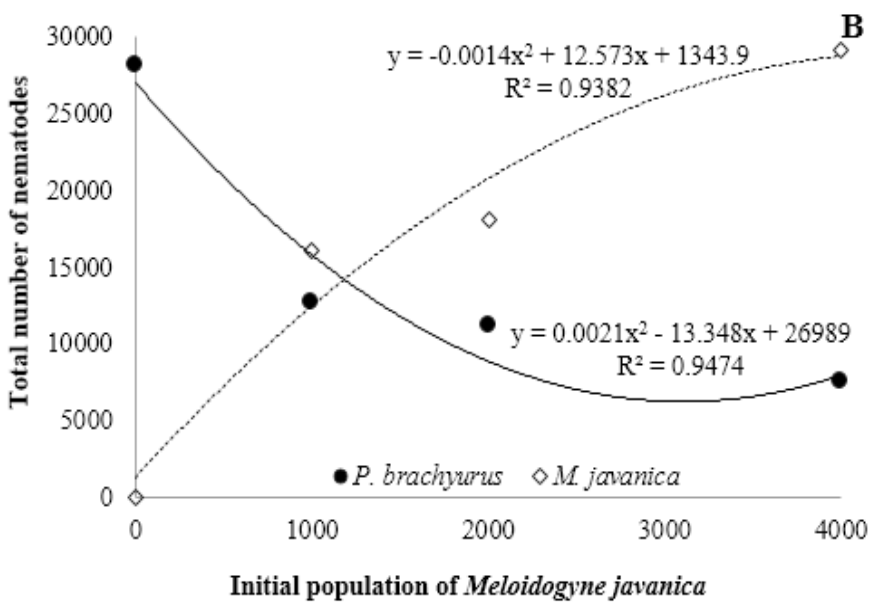

Figure 1. Total number of $M$. javanica and P. brachyurus per root system of soybean 65 days after inoculation with 1000 specimens of $P$. brachyurus and M. javanica population ranging from zero to 4000 eggs (A: Experiment 1; B: Experiment 2). 

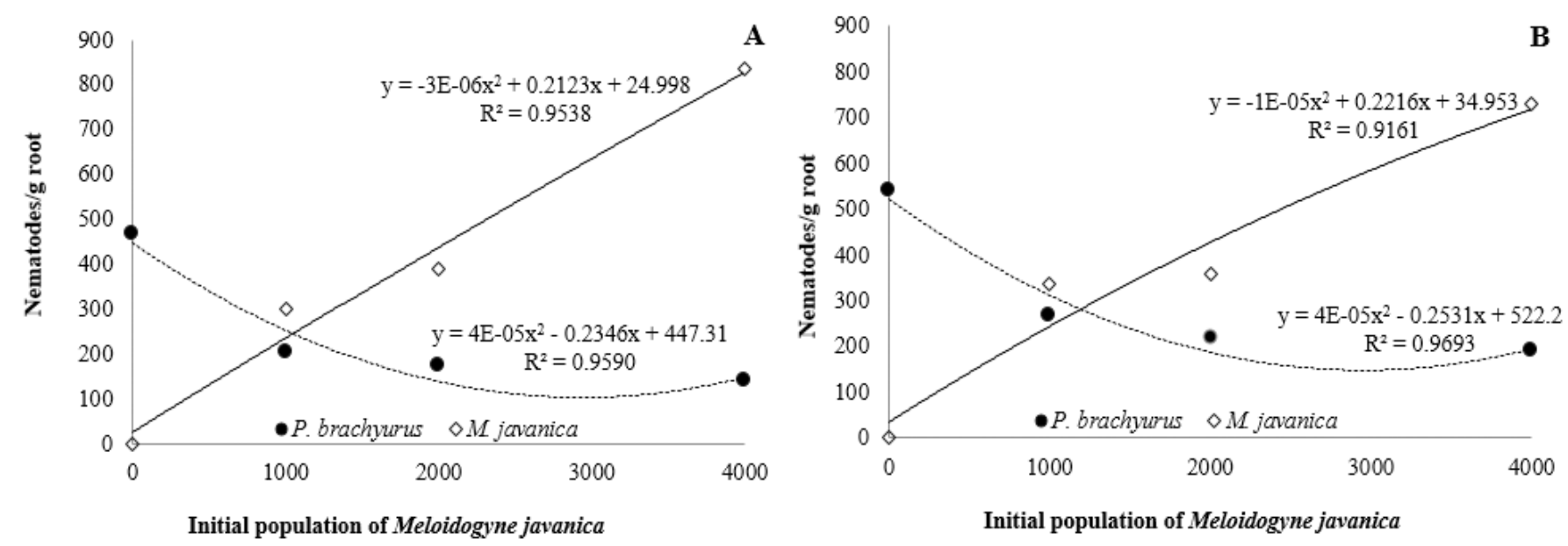

Figure 2. Nematode/g soybean root 65 days after inoculation with 1000 specimens of $P$. brachyurus and $M$. javanica population ranging from zero to 4000 eggs (A: Experiment 1; B: Experiment 2).

population from zero to 4000 eggs reduced the soybean height by 38.0 and $41.0 \%$ in experiments 1 and 2, respectively (Figure $3 \mathrm{~A}$ ). Similar results were obtained for root weight $(\mathrm{g})$ : reductions of 31.8 and $23.9 \%$ were observed after the increase in $M$. javanica population from zero to 4000 eggs in experiments 1 and 2, respectively (Figure 3B).

Decreases in the shoot fresh weight were 48.0 and $38.0 \%$ (experiments 1 and 2, respectively) when $M$. javanica population increased from zero to 4000 eggs (Figure 4A). The results obtained for shoot dry weight were also similar to those of the other vegetative parameters, showing decreases of 58.0 and $54.0 \%$ in experiments 1 and 2, respectively (Figure 4B).

The present study demonstrated that the increase in the initial population of $M$. javanica dramatically reduced $P$. brachyurus reproduction in soybean cv. BRS/MT Pintado. Nevertheless, both species managed to parasitize the crop and significantly increased their populations 65 days after inoculation.

Inoculation of 4000 eggs of M. javanica reduced by 79 and $73 \%$ (experiments 1 and 2, respectively) the total number of $P$. brachyurus, compared to the treatment that did not involve inoculation of $M$. javanica. Similarly, the number of $P$. brachyurus/g root reduced by 69 and $65 \%$, respectively. These results corroborate the study carried out by Herman et al. (16), who assessed the effects of separate or combined inoculations of $M$. javanica and P. brachyurus at growing population levels in soybean varieties and found that, in the interaction, $M$. javanica reduced by 80 to $85 \%$ the reproductive potential of $P$. brachyurus, while the reduction observed for M. javanica was only $30 \%$. Another study involving the same pathosystem showed that both species parasitized soybean, but the nematodes, especially P. brachyurus, were negatively affected by the competition, compared to simple infestations (9).

The negative effect of the genus Meloidogyne on Pratylenchus was investigated and demonstrated in other crops. For example, in alfalfa and red clover subjected to two treatments: 1) simultaneous inoculation of M. incognita and Pratylenchus penetrans (Cobb) Filipjev and Schuurmans Stekhoven, and 2) inoculation of $M$. incognita six days earlier, $M$. incognita reduced the reproductive potential of $P$. penetrans, regardless of the time of inoculation (4). Similarly, $M$. incognita reduced the penetration and the reproduction of Pratylenchus coffeae Zimmermann in mung bean (Vigna radiata L.), regardless of the time of inoculation and inoculum level (27). Advantage of sedentary endoparasites over migratory endoparasites was also observed in the reduction of Belonolaimus longicaudatus Raup by Heterodera glycines Ichinohe and $M$. incognita eleven weeks after inoculation in soybean (6).

Interaction tests involving $M$. incognita and $P$. penetrans, using
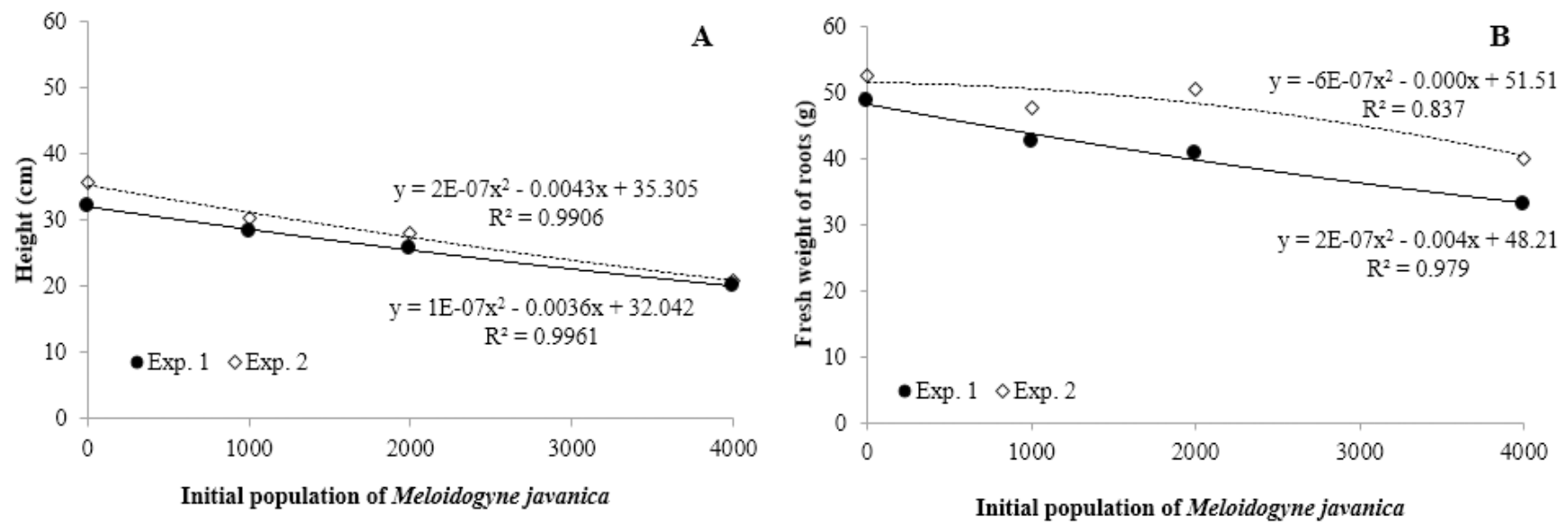

Figure 3. Height (A) and root fresh weight (B) of soybean 65 days after inoculation with 1000 specimens of $P$. brachyurus and $M$. javanica population ranging from zero to 4000 eggs. 

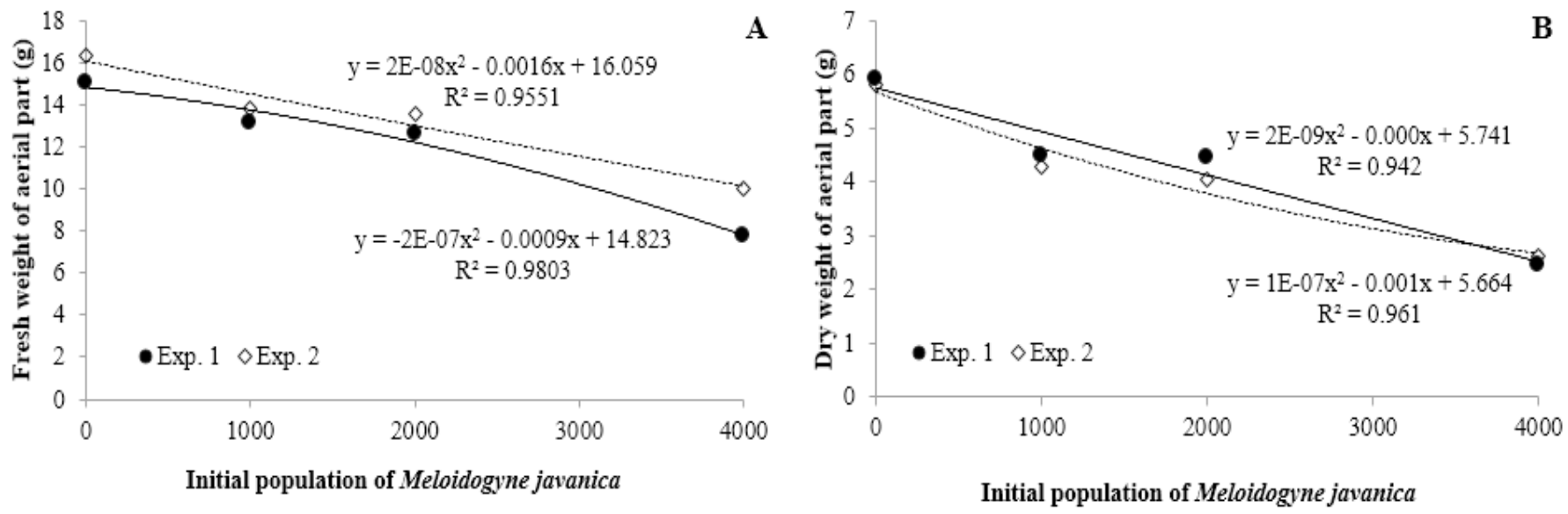

Figure 4. Shoot fresh (A) and dry weight (B) of soybean 65 days after inoculation with 1000 specimens of P. brachyurus and M. javanica population ranging from zero to 4000 eggs.

split root of tomato, showed that the inhibition was not associated only with competition for feeding sites, but also with the change in the concentration of plant growth regulators (8). However, this was not observed for other associations involving the genera Meloidogyne and Pratylenchus (28).

In the present study, P. brachyurus was put in an advantageous position as it was inoculated at the infective stages, while $M$. javanica was inoculated in form of eggs. In addition, the root-knot nematode was more competitive than the root-lesion nematode since, with the same initial inoculum level (1000 nematodes), M. javanica population was greater. Similarly, inoculation of $P$. coffeae two or four days before $M$. incognita did not result in statistical difference in the penetration of the first (27).

However, competitive advantage of sedentary endoparasites over migratory endoparasites is not a rule, and there are reports of suppression of $M$. incognita and M. arenaria (Neal) Chitwood populations in the presence of $P$. brachyurus in cotton plant roots (13). Besides, infection by $M$. incognita has stimulated the penetration of Hoplolaimus columbus Sherem soybean cv. Davis (15) and reproduction in cotton plant (19). In a study conducted by Melakerbehan \& Dey (21), P. penetrans was negatively affected by $H$. glycines only when the inoculum level of the sedentary endoparasite was $75 \%$ higher than that of the migratory endoparasite.

According to Santos (23), the predominance of one species during parasitism of Meloidogyne and Pratylenchus can be considered under different aspects because Meloidogyne females produce, on average, four to six times more eggs than Pratylenchus females, which is a competitive advantage. Moreover, the eggs of Meloidogyne are protected from natural enemies and lack of humidity inside the egg masses secreted by the females, which does not happen with the eggs of Pratylenchus deposited on the soil. On the other hand, if the initial infestation of Pratylenchus is heavy, there will be extensive root necrosis and, since Meloidogyne is a sedentary nematode that needs active feeding sites, parasitism may not progress.

Regarding the vegetative parameters, joint infestation has caused greater reduction in soybean growth than simple infestation by $P$. brachyurus, which is consistent with previous evidence involving the association between M. incognita and P. brachyurus in soybean (16). However, there are also contrasting findings, as tobacco growth has already been observed to be more severely affected by simple infestations of $P$. brachyurus than when inoculated with mixed populations of $P$. brachyurus and $M$. incognita (22). The impact of this type of infection on plant growth has been hypothesized to be generally negative, though not always resulting in greater damage than in isolated infections (7). According to the above-mentioned author, this can be explained because the result depends on the involved nematode species, on the host susceptibility of and on the initial nematode population, leading to significant differences in results in the literature.

\section{ACKNOWLEDGMENTS}

We thank CNPq (National Council for Scientific and Technological Development), for granting the Master's scholarship to the first author and the Productivity and Research scholarship to the second author.

\section{REFERENCES}

1. Antonio, H.; Oliveira, M.C.N. Estimativa das perdas causadas por Meloidogyne javanica em lavouras de soja. Nematologia Brasileira, Piracicaba, v.13, n.1, p.6, 1989.

2. Asmus, G.L. Ocorrência de nematoides fitoparasitos em algodoeiro no estado de Mato Grosso do Sul. Nematologia Brasileira, Brasília, DF, v.28, n.1, p.77-86, 2004.

3. Boneti, J.I.S.; Ferraz, S. Modificação do método de Hussey and Barker para extração de ovos de Meloidogyne exigua de raízes de cafeeiro. Fitopatologia Brasileira, Brasília, DF, v.6, p.553, 1981.

4. Chapman, R.A.; Turner, D.R. Effect of Meloidogyne incognita on reproduction of Pratylenchus penetrans in red clover and alfafa. Journal of Nematology, St. Paul, v.7, n.1, p.6-10, 1975.

5. Dias, W.P.; Garcia, A.; Silva, J.F.V.; Carneiro, G.E.S. Nematoides em soja: identificação e controle. Londrina, PR: Embrapa Soja, 2010. 76p. Circular Técnica 76.

6. Dickson, D.W.; McSorley, R. Interaction of three plant-parasitic nematode in corn and soybean. Supplement to the Journal of Nematology, St. Paul, v.22, p.783-791, 1990.

7. Eisenback, J.D. Interactions among concomitant populations of nematodes. In: Sasser, J.N.; Carter, C.C. (Ed.). An advanced treatise on Meloidogyne. Biology and control. Raleigh: North Carolina State University Graphics, 1985. p.193-213.

8. Estores, R.A.; Chen, T.A. Interactions of Pratylenchus penetrans and Meloidogyne incognita as coinhabitants in tomato. Journal of Nematology, St. Paul, v.4, n.3, p.170-174, 1972.

9. Ferraz, L.C.C.B. Interactions between Pratylenchus brachyurus and 
Meloidogyne javanica in soybean. Scientia Agricola, Piracicaba, v.52, n.2, p.305-309, 1995a.

10. Ferraz, L.C.C.B. Patogenicidade de Pratylenchus brachyurus a três cultivares de soja. Nematologia Brasileira, Piracicaba, v.19, n.1, p.1-8, 1995b.

11. Ferraz, L.C.C.B. O nematoide Pratylenchus brachyurus e a soja sob plantio direto. Revista Plantio Direto, Passo Fundo, v.95, p.23-27, 2006.

12. Ferreira, D.F. Sisvar. Versão 4.2. Lavras:: UFLA, 2003.

13. Gay, C.M.; Bird, G.W. Influence of concomitant Pratylenchus brachyurus and Meloidogyne spp. on root penetration and population dynamics. Journal of Nematology, St. Paul, v.5, n.3, p.212-217, 1973.

14. Goulart, A.M.C. Aspectos gerais sobre nematoides das lesões radiculares (Gênero Pratylenchus). Planaltina, DF: Embrapa Cerrados, 2008. 30p.

15. Guy, D.W.; Lewis, S.A. Selective migration and root penetration by Meloidogyne incognita and Hoplolaimus columbus on soybean roots in vitro. Journal of Nematology, St. Paul, v.19, n.3, p.390-392, 1987.

16. Herman, M.; Hussey, R.S.; Boerma, H.R. Interactions between Meloidogyne incognita and Pratylenchus brachyurus on soybean. Journal of Nematology, St. Paul, v.20, n.1, p.79- 85, 1988.

17. Hirakuri, M.H.; Lazzarotto, J.J. Evolução e perspectiva de desempenho econômico associadas com a produção de soja nos contextos mundiais e brasileiro. Londrina, PR: Embrapa Soja, 2011. 67p.

18. Inomoto, M.M. Importância e manejo de Pratylenchus brachyurus. Revista Plantio Direto, Passo Fundo, v.108, 2008. Disponível em: $<$ http://www.plantiodireto.com.br/?body $=$ cont_int\&id=894>. Acesso em: 28 Jan. 2015

19. Kraus-Schmidt, H.; Lewis, S.A. Dynamics of concomitant populations of Hoplolaimus columbus, Scutellonema brachyurum, and Meloidogyne incognita on cotton. Journal of Nematology, St. Paul, v.13, n.1, p.41-48, 1981

20. Lehman, P.S.; Antonio, H.; Barker, K.R. Ocorrência de nematoides em soja nos estados de Minas Gerais, Goiás e Mato Grosso. Nematologia Brasileira, Piracicaba, v.2, p.29-32, 1977.

21. Melakerbehan, H.; Dey, J. Competition between Heterodera glycines and Meloidogyne incognita or Pratylenchus penetrans: independent infection rate measurements. Journal of Nematology, St. Paul, v.35, n.1, p.1-6, 2003.

22. Ogbuji, R. O. Effect of Meloidogyne incognita and Pratylenchus brachyurus singly and combined on growth of Nigerian tobacco (NTC5). Nematropica, Auburn, v.8, n.1, p.62-66, 1978.

23. Santos, J.M. Estudos das principais espécies de Meloidogyne goeldii que infectam o cafeeiro no Brasil com descrição de Meloidogyne goeldii sp.n. 1996. 153f. Tese (Doutorado em Agronomia/Proteção de Plantas)-Faculdade de Ciências Agronômicas, Universidade Estadual Paulista, Botucatu.

24. Silva, C.M.; Santos, M.A. Levantamento de nematoides na cultura algodoeira. Nematologia Brasileira, Piracicaba, v.21, n.1, p.22-23, 1997.

25. Silva, J.F.V.; Carneiro, R.G. Levantamento de nematoides associados à cultura do algodão no Paraná. Nematologia Brasileira, Piracicaba, v.19, n.1, p.13, 1994.

26. Silva, R.A.; Serrano, M.A.S.; Gomes, A.C.; Borges, D.C.; Souza, A.A.; Asmus, G.L.; Inomoto, M.M. Ocorrência de Pratylenchus brachyurus e Meloidogyne incognita na cultura do algodoeiro no Estado do Mato Grosso. Fitopatologia Brasileira, Brasília, DF, v.29, n.3, p.337, 2004

27. Tsai, B.Y. Competition between Pratylenchus coffeae and Meloidogyne incognita. Plant Pathology Bulletin, Taiwan, v.17, p.271278, 2008.

28. Umesh, K.C.; Ferris, H.; Bayer, D.E. Competition between the plant parasitic nematodes Pratylenchus neglects and Meloidogyne chitwoodi. Journal of Nematology, St. Paul, v.26, n.3, p.286-295, 1994. 